\title{
EDUKASI GIZI UNTUK PENINGKATAN KUALITAS MENU ANAK BALITA DENGAN KONSUMSI GONAD BULU BABI SEBAGAI SUMBER PROTEIN ALTERNATIF PADA KELUARGA ETNIS BAJO SOROPIA
}

\author{
Nutrition Education to Improve Quality of Menu for Children Under-Five through Consumption of \\ Sea Urchin Gonads as an Alternative Source of Protein among Bajo Soropia Ethnic Family
}

\author{
Wiralis $^{1}$, Teguh Fathurrahman ${ }^{1}$, Hariani ${ }^{1}$, Wahyu Puji Nugraheni ${ }^{2}$ \\ ${ }^{1}$ Poltekkes Kemenkes Kendari Jurusan Gizi \\ 2Pusat Penelitian dan Pengembangan Humaniora dan Manajemen Kesehatan \\ E-mail: wiralisgizimedik@gmail.com
}

\section{ABSTRACT}

Bajo tribe rely on seafood as a source of family food. In the west wind season, the fishermen can not go for fishing resulting in unavailability of protein rich food source, especially in the menu of children underfive. The research objective is to study whether intervention of nutrition education may change the family perception through improvement in knowledge, attitudes and skills in order to increase the quality of the children under-five diet through the utilization of sea urchin gonads. The research method was preexperimental using pre- and post-test design to assess the impact of nutrition education with the method of group counseling, accompaniment of family, and finally competition of urchin gonads dish product for children under-five meals among $\mathbf{5 0}$ families in the Bokori and Mekar villages. Nutrition education carried out for 4 months. The results showed that the mean knowledge improvement of 32.8 points, attitude was 31.9 points and skills was 92.7 points and these were significant achievement using t-test $(p<0.05)$. In conclusion, through nutrition education, there were increasing in knowledge, attitude and practice to support health and nutrition. The family has been able to process more varied sea urchin gonads. In addition, there was increasing interest and acceptance of family in sea urchin gonads as an important part of the family menu, especially for children under-five.

Keywords: sea urchin gonads, family dish, nutrition education, children under-five, Bajo Soropia

\section{ABSTRAK}

Suku Bajo mengandalkan hasil laut sebagai sumber pangan keluarga. Pada musim angin barat, nelayan tidak melaut, mengakibatkan tidak tersedia bahan pangan sumber protein, khususnya pada menu anak balita. Tujuan penelitian melakukan edukasi gizi untuk mengubah persepsi keluarga dengan perbaikan pengetahuan, sikap dan keterampilan serta meningkatkan kualitas menu anak balita melalui pemanfaatan gonad bulu babi (sea urchin gonads). Metode penelitian pre-eksperimen dengan desain pre-post test untuk menilai hasil intervensi berupa edukasi gizi dalam bentuk penyuluhan kelompok, pendampingan dan lomba mengolah gonad bulu babi untuk anak balita. Sampel terpilih adalah ibu anak balita sebanyak 50 orang. Intervensi dilakukan selama 4 bulan dari Agustus sampai November 2014. Hasil penelitian menunjukkan, terdapat peningkatan rerata pengetahuan sebesar 32,8 poin; peningkatan sikap positif yang mendukung praktik kegizian 31,9 poin serta rerata keterampilan 92,7 poin. Uji statistik dengan $t$-test menunjukkan perbedaan signifikan. Terdapat peningkatan pengetahuan gizi, sikap positif dan praktik gizi setelah intervensi dan terjadi perubahan kesadaran dan ketertarikan dalam evaluasi dan uji coba nilai bahwa gonad bulu babi dapat menjadi sumber protein menu anak balita pada musim angin barat.

Kata kunci: gonad bulu babi, hidangan keluarga, edukasi gizi, anak di bawah lima tahun, Bajo Soropia 


\section{PENDAHULUAN}

$\mathrm{M}$ engakhiri segala bentuk malnutrisi, termasuk kekurangan gizi, pada anak adalah target kedua dari Tujuan Pembangunan Berkelanjutan (SDGs), yakni mengakhiri kelaparan, mencapai ketahanan pangan, memperbaiki gizi, dan meningkatkan pertanian berkelanjutan. ${ }^{1}$ Kekurangan gizi pada anak balita masih menjadi masalah kesehatan di Indonesia, termasuk di kawasan pesisir seperti di Sulawesi Tenggara. Stunting dan beratkurang (gizi kurang dan gizi buruk) dialami oleh 42,6 dan 23,9 persen $(15,9 \%$ dan $8,0 \%)$ anak balita di Sulawesi Tenggara; di atas prevalensi nasional $(37,2 \% \text { dan } 19,6 \%)^{2}$

Penyebab kekurangan gizi pada anak itu multisektor, meliputi penyebab langsung (level individu), utama (level keluarga), dan dasar (level masyarakat). Kekurangan gizi pada anak balita ialah hasil kombinasi ketidakcukupan asupan zat gizi dan kejadian infeksi. Ada tiga penyebab utama yang menimbulkan hasil tersebut: kerawanan pangan rumah-tangga; layanan kesehatan yang tidak memadai dan lingkungan yang tidak sehat; serta ketidakmemadaian perawatan untuk anak dan ibu. ${ }^{3}$ Ketiga penyebab utama itu didasari oleh faktor ekonomi, sosiopolitis, hukum, dan budaya, dengan kemiskinan yang berperan sentral.3,4 Unsur budaya menciptakan susunan hidangan dan pola pemberian makanan, serta kebiasaan makan individu, yang terkait dengan faktor memilih dan mengonsumsi makanan (reaksi terhadap efek fisiologis, psikologis, sosial), keter-sediaan pangan, pola sosial, budaya dan faktor individu. ${ }^{5}$

Studi budaya makan 'Tetehe \& Tayong' etnis Bajo di Kecamatan Soropia (2014), ${ }^{6}$ melaporkan, 46 persen asupan energi anak balita kurang $(70-90 \%$ AKG), 14 persen asupan energinya defisit $(<70 \% A K G)$, dan 30 persen asupan proteinnya kurang (70-90\% AKG). Menu anak balita etnis Bajo Soropia tampak tak seimbang, mayoritas terdiri dari makanan pokok (nasi/sagu) dan ikan, bila anggota keluarga ke laut mencari ikan (34\% makan lauk 2-3 kali seminggu, $2 \%$ tidak mengonsumsi lauk hewani; $60 \%$ makan sayur $1-3$ kali seminggu, $16 \%$ tidak; $50 \%$ makan buah $1-3$ kali seminggu, $6 \%$ tidak). Ketika hasil tangkapan ikan berlimpah, jumlah ikan yang dikonsumsi sangat banyak (melebihi kebutuhan, >100 g setiap kali makan).
Pola melaut nelayan etnis Bajo berkaitan erat dengan ketersediaan pangan di tingkat keluarga. Saat musim angin barat, nelayan tak melaut, sehingga ketersediaan pangan di tingkat keluarga menjadi rendah dan terbatas. Kondisi ini tergambar dalam pola menu anak balita yang berubah ketika musim angin barat, yang lebih sering berganti menjadi nasi dengan mi instan dibandingkan nasi/sagu dengan lauk hewani darat, seperti telur. ${ }^{6}$

Salah satu bahan makanan sumber laut etnis Bajo Soropia saat musim angin barat adalah gonad bulu babi, dengan spesies yang terkenal mencakup spesies Tripneustes gratilla dan Mespilia globulus, serta subspesies Diadema setosum dan Echinometra Sp. Untuk anggota keluarga yang sudah besar ( $>5$ tahun), secara turun-temurun nenek moyang etnis Bajo makan gonad (telur) dari bulu babi (sea urchin gonads) tanpa diolah (mentah) atau diolah sederhana. Nilai ini ditunjang oleh ketersediaan bahan yang tinggi, terutama ketika musim angin barat. Makan pangan laut juga merupakan kehormatan bagi etnis Bajo karena hal tersebut menunjukkan kemandirian mereka. Itu sesuai dengan moto etnis Bajo, "jangan makan makanan orang daratan", sebab dianggap akan "tunduk pada orang daratan'. 6

Gonad bulu babi dimanfaatkan sebagai 'makanan hiburan' atau lauk, yang bernilai gizi tinggi. Hasil analisis yang telah dilakukan memperlihatkan, pangan laut tersebut kaya gizi untuk memperbaiki kekurangan gizi anak dengan memperbaiki sistem kekebalan tubuhnya. Anak yang kekurangan gizi sering sakit, yang tidak dapat diperbaiki hanya dengan meningkatkan kualitas makanan, tetapi diperlukan upaya pengobatan yang dipadukan dengan makanan. Sudah diketahui potensi gonad bulu babi sebagai obat yang dapat menunjang mutu menu anak balita dan memperbaiki mutu kesehatannya. Permasalahannya, pada etnis Bajo di lokasi penelitian, gonad bulu babi tidak diberikan pada anak balita karena alasan budaya. Untuk memperbaiki penerimaan masyarakat terhadap gonad bulu babi sebagai bagian dari menu anak balita etnis Bajo, diperlukan upaya edukasi. ${ }^{6}$

Edukasi gizi merupakan salah satu upaya kulturisasi nilai-nilai yang mendukung praktik kegizian yang terdapat di masyarakat. Edukasi gizi bertujuan meningkatkan gizi masyarakat, terutama golongan rawan gizi, seperti anak balita, melalui upaya mengubah pengetahuan, 
sikap dan keterampilan dalam mengolah makanan untuk mengubah perilaku yang baik terkait gizi.

Untuk mengatasi masalah kekurangan asupan protein, khususnya pada anak balita, manfaat gonad bulu babi merupakan kearifan lokal masyarakat Bajo sebagai alternatif mengatasi masalah rendahnya asupan protein pada musim barat (nelayan tidak melaut karena ombak tinggi). Tujuan penelitian adalah melakukan edukasi gizi untuk mengubah persepsi keluarga dengan perbaikan pengetahuan, sikap dan keterampilan, serta meningkatkan kualitas menu anak balita melalui pemanfaatan gonad bulu babi.

\section{METODE PENELITIAN}

Jenis penelitian adalah pre-eksperimen dengan desain pre-post test group. Intervensi dalam bentuk edukasi gizi. Edukasi gizi menggunakan metode penyuluhan kelompok, pendampingan, pameran dan perlombaan.

Teknik penyuluhan berupa ceramah dan tanya-jawab. Alasan pemilihan teknik penyuluhan adalah jumlah sampel cukup besar, yaitu 20-30 orang setiap kelas. Penyuluhan menggunakan media leaflet dan lembar balik yang berisi informasi tentang makanan seimbang, sumber nilai gizi bahan pangan, kandungan gizi gonad bulu babi (sea urchin gonads), teknik persiapan yang dapat menjamin kualitas sanitasi gonad bulu babi dan variasi pengolahan. Pelaksana atau tutor pada kegiatan intervensi dilakukan oleh peneliti. Materi disusun dalam bentuk leaflet dan lembar pendidikan yang didasarkan pada kebutuhan informasi untuk menunjang proses pendidikan gizi. Leaflet dan lembar pendidikan yang dikembangkan menggunakan bahasa Bajo untuk memudahkan pemahaman masyarakat. Leaflet dan lembar pendidikan didesain oleh peneliti.

Penyuluhan dilakukan 4 kali selama penelitian dan pameran dilakukan satu kali di akhir kegiatan penelitian. Pendampingan ditujukan untuk mengingat-kan kembali materi penyuluhan yang dilakukan dengan cara silaturahmi pada keluarga anak balita yang mendapat edukasi gizi. Pen-dampingan dilakukan oleh peneliti. Pameran dipilih untuk mengukur inovasi variasi pengolahan gonad bulu babi keluarga anak balita.
Efek pendidikan gizi dilakukan dengan mengukur perubahan pengetahuan dan sikap terkait dengan praktik gizi dan keterampilan menggunakan perbedaan skor hasil pengukuran sebelum dan setelah edukasi gizi, dilanjutkan dengan uji statistik menggunakan $t$-test paired. Pengukuran tambahan untuk menilai keterampilan pengolahan gonad, dilakukan lomba menu mengolah gonad untuk anak balita dan dinilai secara deskriptif, diukur dengan teknik observasi sebelum dan setelah pendampingan, serta mengukur interest dan uji coba nilai masyarakat melalui lomba dan pameran olah gonad.

Data karateristik sampel dan keluarga dikumpulkan dengan metode wawancara menggunakan alat bantu kuesioner. Penelitian dilakukan di Desa Bokori dan Mekar Kecamatan Soropia, Kabupaten Konawe, Sulawesi Tenggara. Populasi adalah keluarga etnis Bajo yang memiliki anak balita yang tinggal di Desa Mekar (60 keluarga) dan Bokori (90 keluarga). Sampel penelitian ini adalah keluarga yang memiliki anak balita (1-5 tahun), yang ditetapkan menggunakan rumus proporsional, dengan hasil jumlah sampel untuk Desa Bokori sebanyak 22 ibu dan Desa Mekar 28 ibu. Penelitian dilakukan selama 4 bulan, mulai bulan Agustus sampai November 2014. Sampel yang memenuhi kriteria sebagai etnis asli Bajo dan telah tinggal di wilayah penelitian selama minimal 10 tahun, kemudian dilakukan randomisasi, yang bersedia ikut dalam penelitian mengisi inform consent. Data yang dikumpulkan meliputi: data karateristik wilayah penelitian atau demografi, data karateristik sampel yang mencakup nama, pendidikan, jumlah anggota keluarga, pekerjaan dan pendapatan, pengetahuan, sikap gizi, dan keterampilan mengolah gonad bulu babi untuk anak balita, persepsi ibu anak balita tentang gonad bulu babi sebagai potensi sumber protein saat musim barat.

Data karateristik wilayah penelitian diperoleh melalui penelusuran dokumen. Data karateristik sampel, seperti nama, pendidikan, dan pendapatan, menggunakan metode wawancara dengan bantuan kuesioner.

Data skor nilai pengetahuan, sikap gizi dan keterampilan diperoleh dengan mengajukan pertanyaan terstruktur secara langsung menggunakan bantuan daftar pertanyaan. Khusus keterampilan mengolah gonad bulu babi diperoleh dengan wawancara dan observasi 
langsung saat keluarga mengolah bahan, serta dilakukan lomba yang dipusatkan di kedua desa, yakni Mekar dan Bokori. Keterampilan mengolah gonad bulu babi meliputi kemampuan ibu mengolah gonad dengan bersih/saniter, jumlah dan jenis olahan yang dapat dilakukan dengan baik untuk menu anak balita.

Data yang dikumpulkan, kemudian dibersihkan dari informasi yang bias, diklasifikasikan berdasarkan kelompok dan dinalisis secara deskriptif menggunakan persentase dan nilai mutlak, seperti untuk kenaikan nilai efek edukasi dan uji analitik menggunakan t-test paired.
HASIL

Karateristik wilayah penelitian

Desa Mekar dan Bokori terletak di pesisir pantai Kecamatan Soropia, Kabupaten Konawe, Provinsi Sulawesi Tenggara. Masyarakat Bokori dan Mekar sebagian besar merupakan etnis Bajo yang mendiami sepanjang pantai Soropia dan membangun rumah di atas laut.

Tabel 1

Karateristik Subjek Penelitian

\begin{tabular}{|c|c|c|}
\hline Karakteristik & $n=50$ & $\%$ \\
\hline \multicolumn{3}{|l|}{ Kelompok umur kepala keluarga } \\
\hline _ $\quad \leq 35$ Tahun & 29 & 58 \\
\hline _ $\quad>35$ tahun & 21 & 42 \\
\hline \multicolumn{3}{|l|}{ Kelompok umur Ibu } \\
\hline$-\quad \leq 32$ tahun & 31 & 62 \\
\hline - $>32$ tahun & 19 & 38 \\
\hline \multicolumn{3}{|l|}{ Jumlah anggota keluarga } \\
\hline$-\quad \leq 4$ orang & 23 & 46 \\
\hline _ $>4$ orang & 27 & 54 \\
\hline \multicolumn{3}{|l|}{ Pekerjaan kepala keluarga } \\
\hline - PNS/POLRI/TNI & 9 & 18 \\
\hline - Swasta & 9 & 18 \\
\hline - Nelayan & 32 & 64 \\
\hline \multicolumn{3}{|l|}{ Pekerjaan Ibu } \\
\hline - PNS & 3 & 6 \\
\hline - Ibu rumah-tangga & 44 & 88 \\
\hline - Lain-lain & 3 & 6 \\
\hline \multicolumn{3}{|l|}{ Pendapatan keluarga } \\
\hline$-\quad \leq 60 \%$ (pendapatan cukup) & 19 & 38,0 \\
\hline _ $\quad>60 \%$ (pendapatan kurang) & 31 & 62,0 \\
\hline \multicolumn{3}{|l|}{ Pendidikan kepala keluarga } \\
\hline _ $\quad$ TS dan SD & 15 & 30 \\
\hline$-\quad>$ SMP & 35 & 70 \\
\hline \multicolumn{3}{|l|}{ Pendidikan ibu } \\
\hline _ $\quad$ TS dan SD & 27 & 54 \\
\hline$-\quad>$ SMP & 23 & 46 \\
\hline Jumlah & 50 & 100,0 \\
\hline
\end{tabular}




\section{Karateristik subjek penelitian}

Sebagian besar subjek (62\%) berusia kurang dari 32 tahun, sebagaimana disajikan pada Tabel 1. Jumlah anggota keluarga sebagian besar $(54 \%)$ lebih dari 4 orang. Pekerjaan 88 persen adalah ibu rumah-tangga. Pendapatan keluarga subjek 60 persen dalam kategori kurang. Persentase terbesar pendidikan subjek penelitian adalah tamat SD sebanyak 44 persen, 26 persen tamat SMP dan sebagian kecil (10\%) tidak sekolah, tamat SMA dan Perguruan tinggi.

\section{Edukasi gizi}

Penyuluhan dan pendampingan yang dilakukan empat kali selama 4 bulan dengan satu kali kegiatan lomba mengolah gonad bulu babi untuk anak balita mampu meningkatkan pengetahuan, memperbaiki sikap dan keterampilan sampel. Materi penyuluhan disusun dalam modul, lembar pendidikan gizi dan leaflet manfaat gonad bulu babi dalam bahasa Bajo. Khusus modul memuat materi tentang konsep gizi seimbang untuk keluarga sehat, triguna makanan, bahan makanan penukar, porsi dan ukuran makanan untuk anak balita dan menyusun menu keluarga sesuai konsep gizi seimbang. ${ }^{7}$
Edukasi gizi diberikan pada subjek penelitian (ibu anak balita) etnis Bajo di Kecamatan Soropia, untuk mengubah pengetahuan, sikap dan keterampilan sebagai upaya perbaikan kualitas menu keluarga balita melalui pemanfaatan gonad bulu babi sebagai sumber bahan pangan tinggi protein, khususnya pada musim barat.

Metode edukasi gizi pada penelitian ini adalah penyuluhan menggunakan media leaflet, lembar pendidikan gizi dan modul pendidikan gizi berbahasa Bajo untuk masyarakat etnis Bajo di Soropia. Selama edukasi pendampingan dilakukan oleh peneliti. Penyuluhan kelompok dilakukan selama 4 kali, dilanjutkan dengan pendampingan untuk mengubah sikap dan membangun keterampilan ibu anak balita di daerah penelitian.

\section{Pengaruh edukasi gizi terhadap pengetahuan}

Edukasi gizi yang dilakukan meningkatkan rerata pengetahuan subjek dari nilai 27,42 menjadi 60,1 dengan peningkatan poin maksimum dari 43 menjadi 85 serta poin minimum dari 21 menjadi 54. Secara rinci disajikan pada Tabel 2. Hasil t-test menunjukkan nilai $p=0,00$

Tabel 2

Rerata Pengetahuan Sebelum dan Setelah Edukasi Gizi

\begin{tabular}{lcccc}
\hline Pengetahuan gizi & Sebelum intervensi & Setelah intervensi & Delta & t-test paired \\
\hline Rerata & 27,42 & 60,1 & 32,8 & \\
SD & 5,3 & 8,3 & & \\
Nilai maksimum & 43 & 85 & 42 & $p=0,00$ \\
Nilai minimum & 21 & 54 & 33 & \\
\hline
\end{tabular}

Tabel 3

Sikap Subjek Penelitian Sebelum dan Setelah Edukasi Gizi

\begin{tabular}{lcccc}
\hline Sikap terhadap kegizian & Sebelum intervensi & Setelah intervensi & Delta & $\begin{array}{l}\text { t-test } \\
\text { paired }\end{array}$ \\
\hline Rerata & 7,64 & 39,5 & 31,9 & \\
SD & 4,67 & 5,5 & & $p=0,00$ \\
Nilai maksimum & 17 & 54 & 37 & \\
Nilai minimum & -4 & 23 & 27 & \\
\hline
\end{tabular}


Tabel 4

Keterampilan Sebelum dan Setelah Edukasi Gizi

\begin{tabular}{lcccc}
\hline Keterampilan Mengolah Makanan & Sebelum intervensi & Setelah intervensi & Delta & $\begin{array}{c}\text { t-test } \\
\text { paired }\end{array}$ \\
\hline Rerata & 552 & 644,8 & 92,7 & \\
SD & 9,7 & 6,4 & & $p=0,00$ \\
Nilai maksimum & 590 & 655 & 65 & \\
Nilai minimum & 545 & 630 & 85 & \\
\hline
\end{tabular}

\section{Pengaruh edukasi gizi terhadap sikap}

Edukasi gizi membangun sikap positif mendukung praktik gizi yang baik, diketahui rerata sikap gizi sebelum intervensi 7,64 menjadi 39,5 dengan nilai maksimum dari 17 menjadi 54 serta nilai minimum dari (-4) menjadi 23. Perbedaan rerata nilai sikap adalah 31,9 ; nilai maksimum 37 dan nilai minimum 27 (Tabel 3).

\section{Pengaruh edukasi gizi terhadap keterampilan}

Edukasi gizi memperbaiki keterampilan subjek dalam mengolah makanan, termasuk mengolah gonad bulu babi yang saniter agar dapat dikonsumsi oleh anak balita. Edukasi gizi meningkat rerata nilai 92,7 dengan peningkatan nilai maksimum 65 poin dan nilai minimum 85 poin. Data disajikan pada Tabel 4.

Edukasi gizi membangun kesadaran, ketertarikan, evaluasi dan uji coba nilai bahwa gonad bulu babi sebagai sumber protein menu anak balita saat musim barat

Ketertarikan dan penerimaan masyarakat di wilayah penelitian diukur saat lomba menggunakan kriteria variasi jenis olahan, penggunaan gonad bulu babi, kebersihan dan organoleptik yang meliputi: keindahan penyajian, rasa, tekstur, dan garnis. Tim juri diketuai oleh ibu ketua penggerak PKK Kecamatan Soropia, dengan anggota adalah ketua 1 Pengurus PKK Kecamatan, ketua Kelompok Kerja (POKJA) 4 PKK Kecamatan Soropia, ketua penggerak PKK Desa Bokori dan Mekar, kepala dan sekretaris desa. Lomba masak Tetehe dan Tayong dilaksanakan secara terpisah antara Desa Mekar dan Bokori.

Hasil lomba yang dilakukan menunjukkan, sajian 10 menu diikuti oleh 9 kelompok dari wilayah penelitian. Adapun menu yang disajikan adalah: Sup Tayong, Perkedel Tetehe dan Tayong, Pepes Tayong, sajian Tetehe dan Tayong mentah, Tetehe dan Tayong kukus, Tetehe dan Tayong bakar, Telur Dadar isi Tayong, Sambel Goreng Tayong, Kandoang Tetehe dan Tayong. Nilai organoleptik sup, perkedel, pepes, telur dadar isi, sambel goreng dan kandoang memiliki rasa, tekstur, aroma yang disukai dari penilaian juri dan diterima oleh anak balita yang hadir pada saat lomba. Sajian gonad mentah, rebus dan bakar hanya disukai oleh masyarakat yang mengonsumsi gonad bulu babi.

\section{BAHASAN}

Keberhasilan intervensi edukasi gizi pada penelitian ini dilakukan melalui evaluasi pengetahuan, sikap dan praktik gizi serta penerimaan olahan gonad bulu babi oleh anak balita yang disajikan saat pameran.

Penyuluhan adalah bentuk edukasi untuk mengubah pengetahuan dengan tujuan akhir mengubah perilaku. Untuk mempercepat perubahan dan internalisasi nilai yang ditawarkan pada penelitian ini penyuluhan dengan kombinasi pendampingan.

Pendidikan dan pengetahuan merupakan faktor tidak langsung yang mempengaruhi perilaku seseorang. Pengetahuan yang dapat diserap seseorang tidak terlepas dari tingkat pendidikan individu secara formal. Makin tinggi pendidikan orang, pengetahuan umumnya semakin luas. ${ }^{8}$

Edukasi gizi yang dilakukan dalam penelitian ini mampu meningkatkan pemahaman subjek penelitian dalam hal ini adalah ibu anak balita dari keluarga etnis Bajo di Soropia akan pentingnya makanan dan gizi untuk tumbuh kembang anak balita, serta mau menerima nilai bahwa gonad bulu babi tidak 
bertentangan dengan budaya Bajo serta terampil mengolah gonad bulu babi secara higienis dan bervariasi.

Edukasi gizi yang dilakukan merupakan suatu proses mempengaruhi keputusan masyarakat untuk memperbaiki pola makan anak balita dan membangun pola makan seimbang yang memenuhi asupan energi, protein, lemak, vitamin dan mineral sesuai kebutuhan anak.

Edukasi yang dilakukan juga bertujuan untuk mengenalkan serta mengadopsi nilai bahwa gonad bulu babi bernilai gizi dan tidak berbahaya bila diberikan pada anak balita, memberikan pengetahuan tentang konsep gizi seimbang, untuk mendukung alih pengetahuan melalui lomba masak untuk menu anak balita dengan tujuan untuk memperkuat nilai-nilai budaya yang positif mendukung perbaikan gizi keluarga dan anak balita. Nilai budaya merupakan informasi untuk menguatkan perilaku gizi yang meliputi pengetahuan, sikap dan keterampilan praktik mengolah makanan yang baik.

Edukasi gizi pada penelitian ini mampu meningkatkan 32,8 poin rerata pengetahuan subjek penelitian lebih tinggi, yakni skor $60,1 \pm 8,3$ dibandingkan sebelum intervensi, yaitu memiliki skor $27,42 \pm 5,3$. Skor penelitian ini lebih rendah dibandingkan dengan skor pendidikan gizi yang dilakukan oleh Nuryanto dkk (2014) dua kali ceramah dengan media booklet hasil skor pengetahuan gizi meningkat dari $62,39 \pm 12,5$ poin menjadi $72,31 \pm 17,01$ yang dilakukan pada anak SD.8) Peningkatan skor pengetahuan yang lebih rendah pada penelitian ini, dapat disebabkan oleh berbagai faktor antara lain perbedaan karateristik subjek penelitian, tingkat pendidikan, media informasi keluarga, tempat tinggal (kota dan desa) dan media yang digunakan, mempengaruhi pencerapan informasi. Sebagaian besar subjek penelitian ini tamat SD dan pola hidup pesisir pantai dengan pendapatan yang rendah dimungkinkan akses terhadap berbagai informasi akan semakin sedikit, meskipun dengan metode sederhana seperti penggunaan bahasa setempat (Bajo), media yang digunakan banyak gambar dan mudah untuk dipahami oleh audiens. Rendahnya pendidikan dapat menghambat penerimaan informasi bila menggunakan bahasa yang bukan bahasa ibu. Hasil yang sama dengan penelitian yang dilakukan oleh Wahyuningsih dkk (2015) pendidikan gizi dilakukan selama satu bulan dengan 8 kali pertemuan, waktu 30 menit setiap pertemuan, menunjukan peningkatan pengetahuan yang signifikan dengan media nutrisi card. ${ }^{9}$

Pada penelitian ini variasi skor pengetahuan setelah intervensi lebih tinggi dibandingkan sebelum intervensi; hasil yang sama dilaporkan pada penelitian Silalahio dkk. ${ }^{10}$ Edukasi gizi adalah upaya memberikan informasi, meskipun terjadi keragaman penerimaan informasi pada saat penyuluhan, keragaman informasi dapat diperkecil saat pendampingan, faktor pendidikan dan bahasa pengantar yang berbeda tidak menjadi hambatan penerimaan informasi yang diberikan. Pendampingan memberikan hasil maksimal untuk mengubah nilai negatif tentang gizi menjadi nilai positif, dan diharapkan nilai yang telah diterima terinternalisasi dalam kehidupan sosial masyarakat dan meninggalkan nilai yang tidak sesuai dengan konsep gizi.

Edukasi gizi dengan penyuluhan dan pendampingan terbukti dapat memperbaiki sikap kegizian dari tidak mendukung praktik gizi menjadi mendukung. hal ini ditunjukkan adanya peningkatan rerata sikap mendukung praktik kegizian dari skor 7,64 $\pm 4,67$ menjadi 39,5 $\pm 5,5$. Edukasi gizi juga meningkatkan ketrampilan sampel, dari skor rerata keterampilan $552 \pm 9,7$ menjadi $644,8 \pm 6,4$.

Edukasi gizi bentuk penyuluhan dan pendampingan meningkatkan pengetahuan, sikap dan keterampilan melalui upaya mempelajari budaya makan, agar mengetahui sumbangan gizi gonad bulu babi terhadap menu keluarga. Lomba menu olah Tetehe dan Tayong adalah proses yang dilakukan untuk mengukur daya terima masyarakat wilayah penelitian terhadap inovasi yang ditawarkan melalui alih teknologi sederhana. ${ }^{11}$

Budaya makan gonad bulu babi adalah kebiasaan makan masyarakat Bajo yang diadopsi secara turun-temurun. Ketersediaan bahan makanan menjadi faktor yang mendorong pemilihan gonad bulu babi sebagai makanan masyarakat Bajo. Pola kehidupan yang sederhana tercermin dari teknik mengolah gonad bulu babi sebagai makanan seperti makan mentah atau direbus dan ditumis pada awal penelitian, edukasi gizi menggeser nilai manfaat gonad bulu babi menjadikan sampel 
tahu manfaat gizi gonad bulu babi sebagai sumber protein yang berkualitas tinggi dan dapat mendukung tumbuh kembang anak balita, khususnya untuk memenuhi asupan protein saat musim angin barat, yaitu bulan agustusdesember; dimana waktu tersebut nelayan etnis Bajo tidak melaut, sehingga tidak tersedia sumber protein dari ikan tangkapan nelayan, implikasinya masyarakat beralih memanfaatkan biota laut lain, seperti bulu babi, teripang, gurita dan kerang-kerangan. Kearifan lokal masyarakat Bajo antara lain tidak menangkap ikan selama 12 bulan penuh, pengaturaan waktu penangkapan berdampak pada

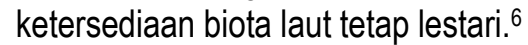

Pengaruh budaya menempatkan gonad bulu babi memiliki fungsi sosial dalam masyarakat di wilayah penelitian, lebih dominan dibandingkan fungsi makanan sumber gizi. Ketersediaan spesies Echinometra Sp. yang lebih tinggi (ditemukan sepanjang tahun di tepi pantai) tidak dapat menjadi alasan sebagai sumber pangan gizi untuk keluarga. Nilai budaya yang sama terhadap pemanfaatan gonad bulu babi pada masyarakat pantai, juga ditemukan pada etnis Bajo di daerah lain, seperti Wakatobi di Sulawesi Tenggara, di Kalimantan, Bali, dan Pulau Seribu Jakarta. ${ }^{6,11}$

Pemanfaatan gonad bulu babi spesies $T$ gratilla dan $M$ globullus sebagai bagian dari susunan menu masyarakat Bajo di wilayah penelitian dapat dioptimalkan untuk mengatasi keadaan gizi kurang dan buruk pada anak balita di wilayah penelitian melalui peningkatan kualitas menu keluarga. Upaya ini telah dicoba pada penelitian melalui kegiatan pendidikan gizi dengan metode penyuluhan kelompok dan pendampingan untuk mempengaruhi keputusan masyarakat dari nilai budaya negatif yang tidak mendukung tujuan umum intervensi yaitu menguatkan nilai budaya positif yang mendukung intervensi.

Nilai budaya negatif yang dipegang oleh masyarakat, seperti tidak memberikan gonad bulu babi pada anak balita karena alasan takut sakit perut, kepercayaan ini diadopsi turun temurun. Edukasi yang diberikan diharapkan mampu mengubah persepsi dan mengadopsi nilai anak balita diberikan gonad karena mengandung nilai gizi tinggi (hasil analisis proksimat), sebagai sumber protein yang murah karena tidak perlu dibeli, dapat diperoleh secara mudah melalui "meti-meti" (aktivitas ibu nelayan mencari kerang dan Tetehe saat air surut). Untuk menghindari sakit perut donad diolah dengan cara yang bersih.

Lebih jauh lagi gonad bulu babi belum menjadi bagian dari bahan makanan pendamping ASI (MP-ASI) karena faktor pengetahuan kurang (belum mengetahui manfaat dan kandungan gizi). Intervensi ini diarahkan pula untuk menguatkan nilai bahwa budaya makan gonad bulu babi pada anak balita merupakan sumber protein yang murah bagi menu keluarga dan dapat mengatasi masalah gizi kurang dan buruk dan dapat digunakan sebagai bagian bahan makanan pendamping ASI.

Potensi gizi berbagai spesies gonad bulu babi digambarkan pada hasil analisis proksimat. seperti protein total, asam amino, lemak total, asam lemak, mineral kalsium dan seng, merupakan unsur gizi yang sangat dibutuhkan untuk menunjang proses tumbuh-kembang anak, termasuk perkembangan otak anak, serta dapat menjadi upaya perbaikan kondisi kurang gizi, bahkan gizi buruk, untuk mengejar tumbuhkembang anak yang memiliki status gizi kurang dan buruk.

Sebagai sumber gizi, gonad bulu babi merupakan makanan bernilai gizi tinggi yang mengandung protein 15,43 persen hingga 25,67 persen. ${ }^{6}$ Kadar protein total dari gonad bulu babi di pesisir Bokori spesies Tripneustes gratilla paling tinggi, mencapai 20,40 persen dari 3 spesies yang dikenal masyarakat etnis Bajo di Kecamatan Soropia. Kandungan asam amino gonad yang dianalisis adalah metionin $(1,97 \%)$, leusin $(1,75 \%)$, valin dan histidin $(1,42 \%)$. Kadar asam amino sistein lebih tinggi $(0,253 \%)$ pada spesies $T$. Gratilla dibandingkan D. setosum $(0,152 \%)$. 6,12

Kandungan lemak total gonad Echinometra Sp. 6,2 persen dan T Gartilla adalah 5,7 persen. Kadar asam lemak laurat yang paling kecil dan yang paling tinggi adalah asam palmitat $(28,254 \%)$. kadar kalsium yang paling tinggi adalah pada gonad Mespilia globulus (8,69\%); kadar seng yang paling tinggi pada gonad Tripneustes gratilla $(3,0 \%){ }^{6}$

Telah dilaporkan pula bahwa gonad bulu babi mengandung a-tokoferol, fenolik dan pigmen yang mirip karotenoid pada gonad $D$. setosum vitamin A, B kompleks dan mineral. ${ }^{13}$

Penguasaan teknologi pengolahan pangan untuk pengawetan juga tidak dimiliki. 
Pengolahan gonad bulu babi pada tingkat keluarga yang diadopsi yaitu dimakan mentah karena alasan organoleptik, bakar atau masak. Gonad bulu babi dapat diolah dengan pengawetan, seperti pengeringan dengan matahari, pengemasan dan fermentasi. ${ }^{13}$

Dalam penelitian ini upaya peningkatan pemanfaatan gonad bulu babi sebagai Makanan Pendamping ASI dianjurkan pada anak yang telah berusia satu tahun, sebagai lauk melalui variasi pengolahan bahan menjadi bentuk hidangan yang lebih variatif dan lebih disukai, melalui peningkatan potensi subjek penelitian pada lomba keterampilan mengolah gonad bulu babi, yang dilakukan sebelum intervensi, juga demo masak saat intervensi berupa pengolahan "nugget" dan "rollade".

Nilai positif yang dipertahankan dari budaya masyarakat Bajo adalah gonad bulu babi sebagai makanan yang memiliki fungsi sosial. Intervensi penelitian ini menekankan pada fungsi sumber pangan bergizi agar dilestarikan, sehingga menjadi pertimbangan keluarga dalam menyusun menu, terutama menu anak balita. Nilai positif lain yang mendukung intervensi adalah tidak adanya stigma negatif, persepsi negatif, perbedaan strata sosial dalam pemamfaatan gonad bulu babi, sehingga memudahkan dalam penguatan nilai yang positif.

Upaya membudayakan makan gonad bulu babi sebagai bagian dari susunan menu anak pada masyarakat Bajo di wilayah penelitian merupakan penguatan yang positif, dengan menggeser kebiasaan pemberian mi instan sebagai pengganti lauk saat ikan tidak diperoleh atau tidak tersedia di rumah-tangga atau di tetangga.

Rendahnya kualitas pola menu anak balita dan asupan protein, terutama pada musim angin barat dapat diatasi dengan merekomendasikan gonad bulu babi sebagai potensi bahan pangan sumber protein, untuk meningkatkan kualitas menu anak balita. Gonad bulu babi mengandung semua unsur gizi yang dibutuhkan anak balita saat pertumbuhan. Kepercayaan bahwa bila anak balita makan gonad bulu babi akan menyebabkan sakit perut, dihindari dengan cara mengolah makanan yang baik.

Budaya makan membentuk karakter makanan masyarakat yang ditransfer secara turun-temurun, dan dipraktikkan oleh masyarakat atau keluarga. ${ }^{14}$ Perubahan sosiobudaya dapat terjadi bila ada kontak dengan budaya asing atau nilai yang berbeda. Perubahan budaya menggambarkan gejala berubahnya struktur sosial dan pola budaya dalam sebuah masyarakat. Nilai budaya makan yang kurang mendukung kesehatan perlu dilakukan pergeseran nilai. Perubahan budaya dapat timbul akibat perubahan lingkungan masyarakat, atau penemuan baru, seperti inovasi-inovasi baru dalam kebudayaan, berupa makan gonad bulu babi tidak menentang nilai sosial budaya Bajo. ${ }^{15}$

Penetrasi budaya dapat dilakukan melalui pendidikan dan pendampingan pada masyarakat. Penetrasi budaya dapat terjadi dengan dua cara, yaitu penetrasi damai (penetration pasifique) dan penetrasi kekerasan (penetration violante). Penetrasi damai adalah masuknya sebuah budaya dengan jalan damai. Penerimaan budaya tersebut tidak mengakibatkan konflik, tetapi memperkaya khasanah budaya masyarakat setempat. Pengaruh kedua budaya ini pun tidak mengakibatkan hilangnya unsur-unsur asli budaya masyarakat. Penyebaran budaya secara damai akan menghasilkan melalui kulturasi, similasi, atau sintesis. Akulturasi adalah bersatunya dua kebudayaan sehingga membentuk kebudayaan baru tanpa menghilangkan unsur kebudayaan asli. Asimilasi adalah bercampurnya dua kebudayaan sehingga membentuk kebudayaan baru. Sintesis adalah bercampurnya dua kebudayaan yang berakibat pada terbentuknya sebuah kebudayaan baru yang sangat berbeda dengan kebudayaan asli. ${ }^{15,16}$

Keluarga belum melakukan praktik olahan gonad bervariasi untuk konsumsi anak, dengan alasan sibuk. Untuk mengukur perubahan perilaku mengolah gonad bervariasi, butuh waktu lebih lama untuk membiasakan nilai baru.

\section{Kelemahan penelitian}

Tidak dapat evaluasi praktik pemberian gonad bulu babi pada anak balita saat musim barat setelah penelitian, karena penelitian berakhir sebelum musim barat berikutnya tiba.

\section{SIMPULAN DAN SARAN}

\section{Simpulan}

Terjadi peningkatan pengetahuan gizi, sikap positif dan praktik gizi yang mendukung 
kesehatan dan kegizian. Keluarga mampu mengolah gonad bulu babi lebih bervariasi. Terjadi interest, penerimaan, evaluasi dan adopsi nilai oleh masyarakat bahwa gonad bulu babi penting menjadi bagian dari menu anak balita.

\section{Saran}

Penelitian lanjutan untuk mengembangkan produk olahan gonad bulu babi yang awet agar dapat menjadi bagian menu anak balita saat musim barat lebih lama.

\section{UCAPAN TERIMA KASIH}

Ucapan terima kasih kami sampaikan kepada Puslitbang Humaniora dan Manajemen Kesehatan di Surabaya, yang telah memberikan biaya penelitian ini; Direktur Poltekkes Kemenkes Kendari; Kepala Dinas Kesehatan Konawe; kepala Wilayah Kecamatan Soropia; kepala puskesmas dan staf puskesmas Soropia; kepala desa, aparat desa dan masyarakat Bokori dan Mekar.

\section{RUJUKAN}

1. GBD 2015 SDG Collaborators. Measuring the health-related Sustainable Development Goals in 188 countries: a baseline analysis from the Global Burden of Disease Study 2015. Lancet. 2016; 388: 1813-50.

2. Tim Riskesdas 2013. Pokok-pokok Hasil Riskesdas Indonesia Tahun 2013: Buku 1. Cetakan Ke-2. Jakarta: Lembaga Penerbit Badan Litbangkes, 2014.

3. UNICEF. The State of the World's Children 1998. Oxfordshire, UK: Oxford University Press, 1998.

4. Black RE, Allen LH, Bhutta ZA, Caulfield LE, de Onis M, Ezzati M, et al. Maternal and child undernutrition: global and regional exposures and health consequences. Lancet. 2008; 371: 243-60.

5. Peribadi. Kedudukan dan Peranan Perempuan dalam Sistem Kekerabatan Masyarakat Bajo: Sebuah Studi Komunitas di Kecamatan Soropia, Kabupaten Kendari, Propinsi Sulawesi Tenggara. Tesis. Bogor: Program Pascasarjana IPB, 2000.

6. Wiralis, Fathurrahman T, Hariani, Nugraheni WP. Budaya makan tetehe dan tayong dalam upaya meningkatkan kualitas menu pada keluarga Suku Bajo Relokasi Pulau Bokori di Kabupaten Konawe. Laporan Akhir Riset Intervensi Kesehatan Berbasis Budaya Lokal. Surabaya: Pusat Humaniora, Kebijakan Kesehatan dan Pemberdayaan Masyarakat Badan Litbangkes \& Poltekkes Kemenkes Kendari, 2015.

7. Herman S. Penggunaan leaflet dalam pendidikan gizi dan pengaruhnya terhadap tingkat pengetahuan ibu. Penel Gizi Makan. 1990; 13: 39-46.

8. Nuryanto, Pramono A, Puruhita N, Muis SF. Pengaruh pendidikan gizi terhadap pengetahuan dan sikap tentang gizi anak sekolah dasar. Jur. Gizi Indonesia 2014; 3(1): 32-6.

9. Wahyuningsih NP, Nadhiroh SR, Adriani M. Media pendidikan gizi nutrition card berpengaruh terhadap perubahan pengetahuan makanan jajanan anak sekolah dasar. Media Gizi Indonesia. 2015; 10(1): 26-31.

10. Silalahio V, Aritonang E, Ashar T. Potensi pendidikan gizi dalam meningkatkan asupan gizi pada remaja putri yang anemi di Kota Medan. Kemas. 2016; 11(2): 98-102.

11. Suryanegara E, Suprajaka, Nahib I. Perubahan sosial pada kehidupan suku Bajo: Studi kasus di Kepulauan Wakatobi, Sulawesi Tenggara. Majalah Globe. 2015; 17(1): 67-78.

12. Silaban BB, Srimariana ES. Kandungan nutrisi dan pemanfaatan gonad bulu babi (Echinothirxs calamaris) dalam pembuatan kue bluder. JPHPI. 2013; 16(2): 108-18.

13. Afifudin IK, Suseno SH, Jacoeb AM. Profil asam lemak dan asam amino gonad bulu babi. JPHPI. 2014; 17(1): 60-70.

14. Dewi M, Aminah M. Pengaruh edukasi gizi terhadap feeding practice ibu balita stunting usia 6-24 bulan. Indones J Hum Nutr [Internet]. 2016; 3(1): 1-8. Available from: http://ijhn.ub.ac.id/index.php/ijhn/article/vie w/138

15. Muhajir N. IImu Pendidikan dan Perubahan Sosial. Jogyakarta: Rake Surasin; 2003.

16. Yudi H. Hubungan Faktor Sosial Budaya dengan Status Gizi Anak Usia 6-24 bulan di Kecamatan Medan, area Kota Medan tahun 2007. Universitas Sumatra Utara, 2008. 